\title{
THE PREPARATION OF LEVULOSE
}

\author{
By Richard F. Jackson, Clara Gillis Silsbee, and Max J. Proffitt
}

\section{ABSTRACT}

It is demonstrated that levulose, the sweetest of the sugars, can be prepared at a moderatc cost from the Jerusalem artichoke or the dahlia. The juices of the artichokes which were examined contained from 8.5 to 23.8 per cent of levulose in the form of soluble polysaccharides, while those from the dahlia contained from 9.3 to 14 per cent mainly in the form of the insoluble polysaccharide, inulin.

The polysaccharides in artichoke juices are converted to sugar by acidifying, immediately upon extraction, with sulphuric or hydrochloric acid and heating from 70 to $80^{\circ} \mathrm{C}$. for 30 to 40 minutes. Inulin may be obtained in pure form from dahlia juices by cooling or freezing the clear juices and may be converted to levulose sirups of 86 to 90 per cent purity.

Artichoke juices which are of sufficiently high purity may permit the direct crystallization of levulose. If too impure, the levulose may be isolated in the form of its insoluble compound with lime. Detailed procedure is given for preparing this compound in pure granular form. The compound is somewhat soluble in the presence of dextrose which is always present in these juices. Experiments on juices which contained 75 per cent of the total sugars in the form of levulose show a recovery of 85 per cent of the levulose in sirups of 94 per cent purity.

Crystallization of levulose has hitherto required the use of expensive organic reagents. A study of its solubilities in water indicated the feasibility of crystallization from aqueous sirups. It is shown that pure white levulose is capable of forming aqueous massecuites which can be purged centrifugally with a facility approaching that of sucrose.

\section{CONTENTS}

II. Abundant sources of levulose

1. Cane sugar. ... 589

2. Beet molasses..... 589

3. Inulin-bearing plants

III. Jerusalem artichoke

1. Description

2. Analytical procedure

3. Defecation........ 597

4. Conversion.

IV. Dahlias......_. 600

1. Description-1.20 600

2. Analytical results....... 601

3. Defecation

4. Separation of inulin

5. Conversion of pure inulin_-_... 604

6. Decomposition of levulose in acid solution 
V. The lime precipitation process

1. Historical

2. Properties of lime levulate

3. The precipitation of lime levulate

VI. Crystallization

1. Historical _...

2. The solubility of levulose in water

3. Crystallization procedure

4. By-products

5. Properties of crystalline levulose

\section{INTRODUCTION}

The ketose sugar, levulose or $d$-fructose $\left(\mathrm{C}_{6} \mathrm{H}_{12} \mathrm{O}_{6}\right)$, is one of the highly nutritious, naturally occurring members of the sugar group. Since it is also the sweetest ${ }^{1}$ of the sugars, it possesses the intrinsic qualifications of a desirable commercial product. Such, however, have been the difficulties encountered in its preparation that the crystalline sugar has hitherto been produced in but small quantities and at prohibitive costs. In the present paper it will be sought to demonstrate that pure crystalline levulose can be produced by methods of procedure readily adaptable to industrial operation at costs of manufacture well within the range of possible commercial development.

The introduction of levulose into ordinary commerce would serve many useful purposes. Supplementary sources of food must inevitably be sought as the needs of the steadily increasing national population approach the capacity of our agricultural resources to supply sustenance. The habits of the plants which store up levulose are. radically different from those which store up sucrose. Thus, regions which are unsuitable for sucrose-producing plants may be thrown open to the hardy plants from which levulose can be produced.

The factories in continental United States which produce sucrose are limited in their period of operation to the short season between the maturing of the beets or cane and the quickly following winter. They are thus idle during the major portion of the year. It is conceivable that a supplementary industry may be based upon the levulose-producing plants, and that the serviceability of these factories may be increased. The cane-producing regions of the South would, moreover, derive benefit from a system of crop rotation in which the root crops of the levulose plants could be alternated with sugar cane.

The previous history of experiments on the preparation of levulose has been summarized and discussed by Harding ${ }^{2}$ and does not

${ }^{2}$ Skinner and Sale, J. Ind. Ing. Chem., 14, p. 522, 1922, report that if the Sweetness of sucrose is 100, levulose is 150. According to Deerr, Int. Sugar J., 24, p. 481, 1922, levulose on the same basis possesses a sweetness of 120, according to Paul, Chom.-Ztg., 45, p. 705, 1921, levulose is 103, and according to Biester, Wood, and Wahlin, Amer. Jour. Physiol., 73, p. 387, 1925, levulose is 173.

2 T. S. Harding, Sugar, 25, p. 406; 1923. 
require a detailed repetition here. In outline the general methods previously employed have consisted of the isolation of levulose in the form of its condensation product, inulin, or from impure liquors in the form of its insoluble lime compound. Inulin has been converted to levulose by hydrolysis in the presence of dilute acids. From the levulose sirups the sugar has been induced to crystallize by the addition of nonaqueous solvents.

The present paper deals with such experiments as it has been possible to perform on a small laboratory scale. The larger problem of adapting these preliminary results to an increased scale of operation has already been undertaken.

\section{ABUNDANT SOURCES OF LEVULOSE}

While levulose occurs abundantly in nature, it is never in plant juices the predominating sugar in uncombined form, as is frequently the case with sucrose. In keeping with its high reactivity, and, indeed, in resemblance to all other hexoses, it tends to condense or to combine with other sugars to form more stable substances of higher molecular weight. It is among these complex derivatives that an abundant source of the crude material for the preparation of levulose must be sought. In the present article only abundant or potentially abundant sources ${ }^{3}$ are discussed.

\section{CANE SUGAR}

For experimental purposes or for the preparation of levulose when expense is not a matter of consideration, the ordinary granulated sugar of commerce offers a readily obtainable source of supply. In a previous paper ${ }^{4}$ have been tabulated the times and temperatures required for complete inversion of sucrose by means of hydrochloric acid. Inversion can also be effected by invertase if this enzyme is available. From the resulting invert sugar the levulose is separated by the lime-precipitation process which will be discussed in detail in a later section of this paper.

\section{BEET MOLASSES}

The discard molasses from beet-sugar manufacture in the United States contains about 50 per cent of sucrose and from 3 to 5 per cent of raffinose. On account of the high raffinose content it is no longer feasible to desugarize it by the Steffen process, and consequently, pending a possiole application of the barium process, it is utilized as a cattle food or in the fermentation industries. It is therefore an inexpensive material and particularly well adapted for the purpose in

a The numerous plants in which levulose or its derivatices have been detected are enumerated in $\nabla$. Lippmann's Die Chemio der Zuckerarten, 1, p. 793; 1904.

B. S. Sci. Paper No. 375, p. 138, 16; 1920. 
hand. The yield of levulose is, however, but 70 per cent of the theory or but 17.5 per cent of the total weight of molasses. Accordingly from a broad standpoint of conservation the production of levulose from beet molasses can be considered good economy only if it is accompanied by a fermentation process for the recovery of the valuable products remaining in the waste water. Since both sucrose and raffinose yield levulose on hydrolysis, there is no danger of the retention of raffinose in the subsequent precipitation by lime.

In a fermentation industry there will be abundant quantities of yeast available for the inversion of sucrose and raffinose. From the yeast the enzyme, invertase, may be extracted and utilized for the inversion reaction in the usual manner, or the yeast may be employed directly without previously isolating the enzyme. Gore ${ }^{5}$ has described in detail the use of yeast for the partial inversion of sucrose sirups. The specifications can readily be modified to effect the complete inversion of the sugars in molasses by adding adequate quantities of yeast. The reaction is carried out at 50 to $60^{\circ} \mathrm{C}$., at which temperature the process of fermentation is inhibited.

Inversion of the sugars in molasses by acid is rendered difficult by the presence of inorganic salts and nitrogenous nonsugars. However, by addition of relatively large quantities of acid it is possible to produce a sufficiently high acidity to effect the hydrolysis. The details of operation may be readily ascertained by experiment.

The separation of the levulose from the inverted molasses is accomplished by the precipitation of lime levulate, which will be described in a later section of this paper. Since beet molasses in its previous history has encountered strongly alkaline solutions, no further defecation than a filtration is required in preparation for the precipitation process.

\section{INULIN-BEARING PLANTS}

A numerous class of plants store up levulose as a reserve carbohydrate in the form of its various condensation products. Many of these compounds have been isolated and have been found to differ among themselves in respect of molecular weight, specific rotation, and the solubility of the compound itself or its barium or calcium derivative. For the present purpose the only variation in property which affects the process of obtaining levulose is the solubility in water. The least soluble condensation product of levulose is the starch-like polysaccharide known as inulin which occurs abundantly in dahlias. Inulin is very slightly soluble in cold water but very soluble in hot water. The remaining condensation products are more solluble than inulin. There appear to be rough relations between

\footnotetext{
${ }^{5}$ H. C. Gore, U. S. Patent No. 1467599, Sept. 11, 1923. Process fol preparing a sugar sirup. Dedicated
} to the frec use of the people of the United States. 
molecular weight, solubility, and levulose purity after conversion. The compounds of lower molecular weight have the higher solubility and lower levulose purity.

Since in the present article we are only concerned with the extraction of levulose, the distinctive properties of these soluble compounds are not significant. We shall, therefore, consider them merely as the soluble group and shall follow Dean ${ }^{6}$ in designating them as levulins, in distinction to the more insoluble inulin. Inulin corresponds in a general way to the starch of glucose chemistry and the levulins to the dextrins. For the sake of brevity we shall occasionally include the whole group of condensation products under the designation, inulins.

Among the many plants which store up condensed levulose are the Jerusalem artichoke, dahlia, chicory, ${ }^{7}$ burdock, goldenrod, and dandelion. It seems extraordinary that the delicate levulose and its derivatives, which are far less stable than glucose and starch, should be the main reliance of some of our most hardy and persistent weeds. We shall consider in detail only the Jerusalem artichoke and dahlia.

\section{JERUSALEM ARTICHOKE}

\section{DESCRIPTION}

The Jerusalem artichoke ${ }^{8}$ (Helianthus tuberosus) is the tuber of a native sunflower. ${ }^{9}$ It occurs frequently as a weed and may be seen growing abundantly in neglected places. The native varieties have been greatly improved, particularly in France, where it was early recognized as a promising source of alcohol. As a result of selection a strain was developed, known as the "Mammoth French White Jerusalem Artichoke," which has been made to acquire a greatly increased size without impairing the hardiness of the plant. It has been our privilege to have enlisted the interest of Hon. Joseph C. Sibley, River Ridge Farm, Franklin, Pa., whose pioneer work on the agricultural aspects of the artichoke has served to demonstrate the value of the artichoke tuber and artichoke hay in the feeding of cattle and, indeed, the tuber as a table delicacy. We take this opportunity to express our indebtedness to Mr. Sibley, without whose kindly

6 A. L. Dean, Amer. Chem. Jour., 32, p. 69; 1904.

7 The root of the chicory (Cichorium intybus), which is occasionally used as an addition to coffeo, is known to have a high inulin content and is employed in Europe to a limited extent for the preparation of levulose. Through the courtesy of William Brotherton, jr., and Harry Oven opportunity has been afforded for the analysis of a sample of cultivated chicory. The analytical work showed that the converted juice possessed the following composition, the percentages being based on the weight of the original roots: Levulose, 18.2 . per cent; total reducing sugar, 24.1; total solids, 27.6; nonsugar, 12.6; purity, 66.2; ratio of levulose to total sugar, 0.755. From these analyses and from such descriptions as have been available it may be judged that the preparation of levulose from this plant would resemble closely that from the artichoke or dahlia.

8 The name applied to this plant has no geographical significance. "Jerusalem" is a corruption of "girasole," a synonym for this variety of artichoke and is useful in distinguishing it from the globe artichoke (Cynara scolymus).

- Bailey, Standard Cyclopedia of Horticulture, 1. 
cooperation the present investigation would have hardly been possible. While there is but little agricultural information in regard to the artichoke to be obtained from general literature, Mr. Sibley has issued a number of highly interesting pamphlets which contain the results of his already extensive experiments on their culture. We can here cite from these monographs ${ }^{10}$ only the most significant aspects of the subject.

The artichoke is indigenous to America and grows freely in practically all parts of the country. It is an extremely hardy plant and adapts itself readily to a great variation in soil and climate. It is resistant to frost and remains uninjured by wintering in the earth where planted. The crop may, therefore, be dug in the late autumn or early spring. The foliage reaches a height of 8 to 10 feet and is apparently highly resistant to the ravages of insects and plant diseases. The entire planting, cultivation, and harvesting of the crop may be accomplished mechanically, the ordinary power potato digger serving admirably the last purpose. Under the favorable conditions existing at Mr. Sibley's farm the crop yields approximately 900 bushels, or about 20 tons, per acre. We quote from his pamphlet of 1922:

It is a plant that has fought for its existence through the extremes of climate, against insect pests in North and South America, and, so far as we have been able to learn, has mastered all its enemies. We know no other crop that can be produced at so small an expenditure of time, labor, or cash.

During the winter of 1923-24 Mr. Sibley submitted adequate lots of tubers for experiment and analysis at significant intervals of time.

The carbohydrates of the Jerusalem artichoke have been the subject of previous investigation. C. Tanret, ${ }^{11}$ finding that both inulin and levulins were present, has isolated and estimated the amount of each of the several condensation products of levulose in the extracted juice. His results are reproduced in Table $1,{ }^{12}$ which also contains a summary of the properties of these various compounds. The columns headed $\left[a_{1}\right]_{\mathrm{D}}$ and $\left[a_{2}\right]_{\mathrm{D}}$ refer to the specific rotations before and after conversion, respectively.

It is apparent that the carbohydrates of lower molecular weight and relatively high solubility predominate in the juices. Tanret is of the opinion that as the artichoke matures the compounds of low molecular weight pass progressively into those of higher molecular weight and lower solubility. This view is, however, at variance with that of Colin, ${ }^{13}$ who states that the young and adult tubers have an identical composition.

\footnotetext{
10 For example, Observations and Experiments with the Mammoth French White Jerusalem Artichoke, Apr. 1, 1924.

11 Bull. Soc. Chem., 3d series, 9, pp. 227, 622; 1893.

12 Compiled from Tanret's article by Colin.

13 Bull. Assoc. Chim. Sucrerie, 37, p. 122; 1919.
} 
TABLE 1.-Tanret's classification of polysaccharides existing in the juice of the Jerusalem artichoke

\begin{tabular}{|c|c|c|c|c|c|c|c|}
\hline & $\begin{array}{l}\text { One } \\
\text { liter }{ }^{1} \text { of } \\
\text { juice con- } \\
\text { tains- }\end{array}$ & $\begin{array}{c}\text { Molecu- } \\
\text { lar weight }\end{array}$ & {$\left[\boldsymbol{\alpha}_{1}\right]_{\mathrm{D}}$} & {$\left[\alpha_{2}\right]_{\mathrm{D}}$} & $\begin{array}{l}\text { Ratio: } \\
\text { Glucose } \\
\text { levulose }\end{array}$ & $\begin{array}{l}\text { Parts } \\
\text { water re- } \\
\text { quired to } \\
\text { dissolve } \\
\mathbf{1} \text { part } \\
\text { at } 15^{\circ}\end{array}$ & $\begin{array}{l}\text { Action of } \\
\text { brewers' yeast }\end{array}$ \\
\hline $\begin{array}{l}\text { Inulin } \\
\text { Pseudo-inulin-.- } \\
\text { Inulenin } \\
\text { Heliantheni-.-. }\end{array}$ & $\begin{array}{l}9 \\
51.0 \\
.6 \\
24.0 \\
14.4\end{array}$ & $\begin{array}{l}4,827 \\
2,610 \\
1,645 \\
1,924\end{array}$ & $\begin{array}{l}-39.5 \\
-32.2 \\
-29.6 \\
-23.5\end{array}$ & $\begin{array}{l}-81.3 \\
-72.0 \\
-70.0 \\
-63.8\end{array}$ & $\begin{array}{r}0.06 \\
.13 \\
.15 \\
.22\end{array}$ & $\begin{array}{r}10,000 \\
350-400 \\
8 \\
1\end{array}$ & $\begin{array}{l}\text { Unfermentable. } \\
\text { Do. } \\
\text { Do. } \\
\text { Difficulty fer- }\end{array}$ \\
\hline Synanthrin & 122.0 & 1,319 & -17.0 & -64.5 & 21 & (2) & Formentable. \\
\hline
\end{tabular}

1 In addition, a liter of juice contains $30 \mathrm{~g}$ sucrose and $9 \mathrm{~g}$ reducing sugar.

2 All proportions.

Other authors ${ }^{14}$ express the opinion that the carbohydrates of the artichoke do not permit of such definite differentiation, and that there is a more or less continuous series of substances with a continuous variation in properties.

The present paper is not concerned with the question of the identity of these compounds. The property of solubility in water is, however, of importance. On account of the low content of inulin and the high content of the soluble levulins their isolation by any simple method was deemed impracticable. The problem then resolves itself into the preparation of the juice for the precipitation of lime levulate.

\section{ANALYTICAL PROCEDURE}

Since no systematic analytical procedure for the analysis of artichokes had been previously described, the methods employed in the present investigation were necessarily at first hastily devised and subjected subsequently to constant variation. Even the final procedure, which alone will be described, leaves much to be desired in respect of convenience and precision.

At the earliest possible moment after receipt the tubers were cleaned of adhering soil with a dry brush and ground through a meat chopper. From the thoroughly mixed pulp $55.8 \mathrm{~g}$ portions or approximately three normal weights of levulose were weighed out on a pulp balance for analysis. The weighed pulp was transferred to a $250 \mathrm{cc}$ dish with $20 \mathrm{cc}$ of water, digested on a steam bath for about an hour, and finally transferred to a small meat-juice press lined with a circular piece of canvas. The extract was pressed from the pulp into a $100 \mathrm{cc}$ volumetric flask. Two $10 \mathrm{cc}$ portions of boiling water were added successively to wash the beaker and pulp and subsequently pressed into the flask. The volumes of water required varied with the condition of the sample, but were so adjusted that the volume of the extract was not more than $90 \mathrm{cc}$. In order to insure the com-

11 A. L. Dean, Am. Chem. Jour., 32, p. 69; 1904.

$61308^{\circ}-26 \dagger-2$ 
plete exhaustion of the sample, a second extraction was made with relatively large additions of boiling water. The first and second extracts were analyzed separately. ${ }^{15}$

(a) Total Dry Substance.-The total extracted solids were determined in a few instances by drying at $100^{\circ}$, by a densimetric method, and by a refractometric estimation in which dry substance was calculated from the sucrose tables of Schönrock. It was found that refractometer solids approximated the solids obtained by drying on sand, and that the densimetric method yielded results considerably at variance from the other methods. Consequently, all dry substance determinations on artichoke juices in this paper were determined by refractometer. Evidently this determination yields at best "apparent" solids, since during the hydrolysis of the inulins an indeterminate quantity of water becomes an integral part of the dry substance. All purities based on these dry substance analyses are then "apparent."

The flask and extract were weighed and a drop removed on a glass rod for refractive index estimation. The amount removed was determined by a second weighing and the appropriate correction applied to the analytical data.

(b) Levulose.-To the extracts which occupied a volume of 85 to $90 \mathrm{cc}$ was added $2.5 \mathrm{cc}$ of $8.12 \mathrm{~N} \mathrm{HCl}$. They were then converted at $70^{\circ} \mathrm{C}$. for 35 minutes and cooled to room temperature. Clarification, at first a puzzling problem, was found to be very simply accomplished by adding 4 to $6 \mathrm{cc}$ of a saturated solution of normal lead acetate. In the presence of the normal acetate and of the acid solution there was found to be no danger of inclusion of levulose in the precipitate. The solution was made to volume and filtered. The filtrate, which was, in general, water white, was polarized at room temperature and at about $60^{\circ} \mathrm{C}$. The hightemperature polarization was corrected for expansion by assuming an expansion coefficient of 0.0003 . The temperature coefficient of the solution under examination divided by a constant, ${ }^{18}$ approximately 0.036 , yielded the number of grams of levulose in $100 \mathrm{cc}$. The method described will be recognized as crude, since the actual differences observed were relatively small and since the assumption was necessary that all differences resulting from a change of temperature were to be ascribed to levulose. Since it is probable that the

\footnotetext{
15 The laborious method of extraction described here was adopted in these early analyses because it was found difficult to employ a digestion method on so large a sample in $100 \mathrm{cc}$. A large sample was necessary in order to give an adequate change in polarization between two temperatures. Subsequent to the type-setting of the present article the reduction method for levulose described by Nyns (Chem. Abs., 19 , p. $1235 ; 1925)$ has been found reliable and permits the use of a small sample. The method adapted to the present problem will be described in Ind. and Eng. Chem., 1926.

${ }^{16}$ Browne, Handbook of Sugar Analysis, p. 297. Wiley \& Sons, New York; 1912. This constant was determined repeatedly during the course of the investigation. Its value appeared to vary slightly with concentration and other conditions and required redetermination with any change in apparatus or manipulation.
} 
other polarizing substances are mainly glucose whose temperature coefficient is zero, the main sources of error are observational.

(c) Reducing Sugars. - Total reducing sugars were determined in an aliquot portion of the filtrate used for the polariscopic data. From this filtrate $7.168 \mathrm{cc}$ was taken by means of a pipette made and calibrated for this purpose and delivered into a $100 \mathrm{cc}$ flask. After neutralization of the acid and addition of sodium sulphate to remove lead the solution was filled to the mark, filtered, and transferred to a burette. The reducing sugars were estimated by the volumetric method of Lane and Eynon ${ }^{17}$ in which methylene blue is employed as an inside indicator. An expanded table based on their data was prepared for varying mixtures of levulose and dextrose, and a control solution was titrated in order to determine the small correction resulting from a slight modification of procedure. Reference of the corrected titer to the table yielded the number of milligrams (m) of reducing sugar in $100 \mathrm{cc}$ of the solution titrated. Then

$$
\frac{\mathrm{m} \times 100 \times 100}{7.168 \times \text { wt. of sample }}=\frac{\mathrm{m} \times 100 \times 100}{7.168 \times 55.8}=\frac{\mathrm{m} \times 100}{4}=\text { per cent reducing sugar. }
$$

It was consequently necessary merely to refer the titer to the table and divide by 4 .

TABLE 2.-Analyses of Jerusalem artichokes from River Ridge Farm, Franllin, Pa.

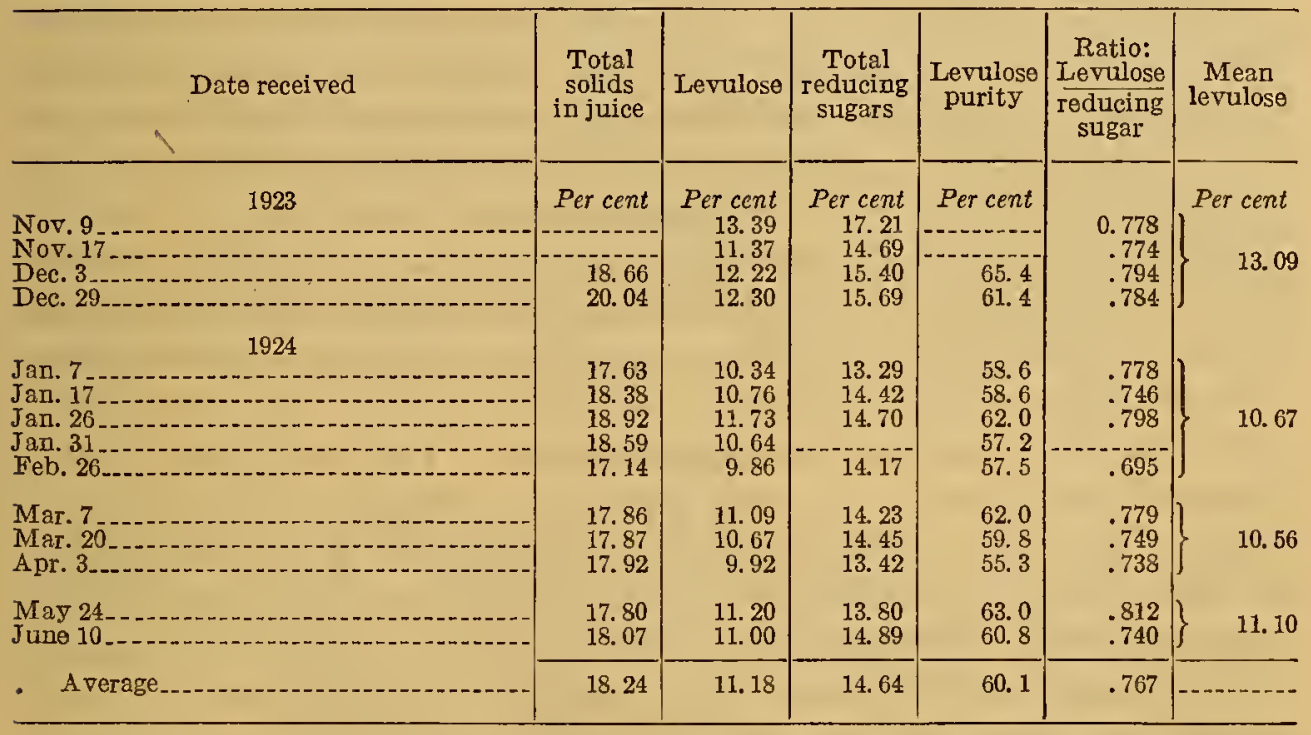

The analytical results are assembled in Table 2. The samples received at the earlier dates were dug from the ground immediately before transmittal. Those of midwinter had been stored by covering with earth after harvesting. The samples submitted in April and May were freshly dug from the fields where they had originally been

17 Jour. Soc. Chem. Ind., 42, p. 32, 1923. 
planted. The sample submitted in June had been kept in cold storage before transmittal.

An observation of the mean levulose content during periods of two months apparently shows that the most advantageous period of extraction is to be found during the months of November and December; that there is considerable loss of sugar during the period of storage; and that the tubers which have remained in the place of original growth have lost about 15 per cent of their levulose content.

On the other hand, it is probable that improved methods of storage which may be devised will result in smaller losses during early winter months. Moreover, it is stated by Mr. Sibley and others that articholses which have wintered in the ground are much larger than those harvested in the autumn. The loss of levulose per unit of area planted would then be smaller than the analyses indicate. The levulose purities are probably unnecessarily low and may undoubtedly be raised by improved methods of extraction and defecation.

The ratio of levulose to total reducing sugar in the converted liquors shows but slight alteration with the advancing age of the tubers. This result is considerably at variance with the previous conclusion reached by Colin, ${ }^{18}$ who, by observing that the specific rotation of the converted liquors diminished from -71 to -50 , concluded that levulose in the tubers was slowly transformed into glucose and sucrose.

It should be pointed out that the specific rotation is not an adequate criterion to permit a judgment on this question, since there are unquestionably nonsugars possessing rotary power which may be present in varying amounts. It is felt that the most direct evidence is furnished by the analytical determinations here presented.

In addition to the systematic analyses on tubers supplied by Mr. Sibley, opportunity has been afforded to examine artichokes from various localities and of different varieties. Of these miscellaneous varieties some were apparently cultivated, others wild; some were white, others possessed a purple cortex. The cultivated tubers frequently attained a relatively large size, averaging about $80 \mathrm{~g}$ in weight. The wild tubers weighed from 20 to $30 \mathrm{~g}$, but, in general, contained a higher percentage of levulose than the cultivated varieties.

In Table 3 are asembled the analytical data. Outstanding features of these data are the extraordinary range of levulose content, from 8.14 to 23.77 per cent, the wide range in levulose purities from 57.0 to 72.8 per cent; the variation in the ratio of levulose to total sugars from 70.2 to 83.8 per cent, and the variation in nonsugars from 12.9 to 19.3 per cent.

Other samples which were received in too deteriorated condition to permit a satisfactory conclusion in regard to their composition showed a ratio of levulose to total sugar as high as 88 per cent.

18 Bull. Assoc. Chim. de Sucrerie, 37, p. 123; 1919. 
TABLE 3.-Analyses of miscellaneous samples of artichokes

\begin{tabular}{|c|c|c|c|c|c|c|c|c|}
\hline Submitted by- & $\begin{array}{c}\text { Date } \\
\text { received }\end{array}$ & $\begin{array}{l}\text { Levu- } \\
\text { lose }\end{array}$ & $\begin{array}{c}\text { Re- } \\
\text { ducing } \\
\text { sugar }\end{array}$ & $\begin{array}{l}\text { Total } \\
\text { solids }\end{array}$ & $\begin{array}{c}\text { Ap- } \\
\text { parent } \\
\text { purity }\end{array}$ & $\begin{array}{l}\text { Ratio: } \\
\text { Levu- } \\
\text { lose }\end{array}$ & $\begin{array}{c}\text { Ratio: } \\
\text { Re- } \\
\text { ducing } \\
\text { sugar } \\
\text { total } \\
\text { solids }\end{array}$ & $\begin{array}{l}\text { Non- } \\
\text { sugar } \\
\text { on } 100 \\
\text { Brix }\end{array}$ \\
\hline $\begin{array}{l}\text { GeorgeF. Lyon, Bingbamton, } \\
\text { N. Y.1 }\end{array}$ & \multirow{3}{*}{ Dec. 29, 1924} & $\begin{array}{l}\text { Per } \\
\text { cent } \\
17.59\end{array}$ & $\begin{array}{l}\text { Per } \\
\text { cent } \\
20.66\end{array}$ & $\begin{array}{l}\text { Per } \\
\text { cent } \\
2415\end{array}$ & $\begin{array}{l}\text { Per } \\
\text { cent } \\
708\end{array}$ & \multirow{3}{*}{$\begin{array}{r}0.815 \\
.691\end{array}$} & \multirow{3}{*}{$\begin{array}{l}0.87 \\
.791\end{array}$} & \multirow{3}{*}{$\begin{array}{c}\text { Per } \\
\text { cent } \\
12.9 \\
20.9\end{array}$} \\
\hline Dr.C.C.McLean, Meadville, & & 17.59 & 20.66 & & 72.8 & & & \\
\hline $\begin{array}{l}\mathrm{Pa} \\
\text { Tilghman Lumber Corp., }\end{array}$ & & 8. 14 & 11.77 & 14.88 & 54.7 & & & \\
\hline $\begin{array}{l}\text { Sellers, S. Coker, Hartsville, S. C- } \\
\text { George F. Lyon, Binghmaton, }\end{array}$ & $\begin{array}{ll}\text { Jan, } & 3,1925 \\
\text { Jan. } & 8,1925\end{array}$ & $\begin{array}{l}13.1 \\
10.0\end{array}$ & $\begin{array}{l}18.4 \\
14.24\end{array}$ & $\begin{array}{l}21.7 \\
17.64\end{array}$ & $\begin{array}{l}60.0 \\
57.0\end{array}$ & .712 & .848 & $\begin{array}{l}15.2 \\
19.3\end{array}$ \\
\hline N. Y. & Jan. 19,1925 & 23. 77 & 29.17 & 33.51 & 70.8 & .815 & .870 & 12.94 \\
\hline $\begin{array}{l}\text { B. Wice, Caldwell, Idabo } \\
\text { George F. Lyon, Binghmaton, }\end{array}$ & Feb. $\quad 9,1925$ & 9. 69 & 13.6 & 17. & 57.0 & .713 & .810 & 17.08 \\
\hline N. Y.1 & Mar. 17, 1925 & 15.3 & 19.5 & & & .784 & & \\
\hline Oreg. ${ }^{A}$ & Mar. 27, 1925 & 18. 15 & 21.68 & 25.09 & 72.5 & .838 & .864 & 13.7 \\
\hline ville, Va............... & Mar. 28, 1925 & 12. 84 & 17. 27 & & & .741 & & \\
\hline
\end{tabular}

1 Purple-skinned articholes.

It is evident that the carbohydrates of the artichoke are very variable in composition, and that Tanret's classification as reproduced in Table 1 applies solely to the particular sample of artichokes with which he experimented and can have no general application. According to Tanret's analyses the group of polysaccharides which he designated synanthrin predominate in the artichoke. In the analytical work here presented the ratio of levulose to total sugar is in many instances greatly in excess of that in synanthrin, and the conclusion seems justified that the degree of condensation of sugar may approach closely that existing in inulin. Conceivably a systematic process of plant breeding would develop new varieties possessing the desirable qualifications of high levulose content, high ratio of levulose to total sugar, high levulose purity, and high yield of tubers.

\section{DEFECATION}

In order to prepare the juices for the subsequent precipitation of the lime levulate, a preliminary clarification is required. In the early experiments an attempt was made to apply a modification of the lime and carbonation process which is successful in beet juice defecation. This process failed completely as a result of the injurious effect of a hot alkaline solution on either the inulin or its isomers. Moreover, the juices, in general, contain some reducing sugar which would inevitably be destroyed. Consequently, it was judged that if lime was to be employed as a defecating agent the process must be conducted at a relatively low temperature. Many experiments were, therefore, performed at 20 to $25^{\circ} \mathrm{C}$. The clarification in every instance was satisfactory, but the filtration was, in general, slow. 
The most satisfactory results were obtained by addition of 0.7 per cent lime (on tubers). An addition of 2 per cent of lime gave a voluminous precipitate, indeed, amounting almost to a paste which suggested precipitation of inulins. This combination was, in general, broken up by carbonation. In every instance there was a considerable loss of levulose amounting to 7 or 10 per cent. It was thus thought that the alkalinity was injurious even at the lower temperatures, and an experiment was tried in which lime and phosphoric acid were added simultaneously and in such proportions that but a slight residual alkalinity resulted. The filtrate showed a loss of about 12 per cent of levulose. The conclusion was reached that two possible causes of loss were encountered in these processes. One was the chemical action of a highly alkaline medium; the other the inclusion of inulins in the precipitate. It seemed desirable, therefore, to avoid both the alkalinity and the formation of a precipitate which could include inulins. Both of these objects were accomplished by converting the inulins before the defecation. This has the added advantage that the acid required for conversion is added to the already acid juice instead of to an alkaline filtrate. The following procedure proved satisfactory:

The expressed juices were immediately acidified with either sulphuric or hydrochloric acid in such quantity as to make the resulting solution one-tenth or one-fifth normal with respect to the acid. The juice was then converted in the manner described below. During the conversion a considerable coagulation of albuminoids occurred, which were subsequently removed by filtration. This precipitate by Kjeldahl analysis was found to contain 9 per cent of nitrogen and may possibly have some value as a fertilizer. Since this material is probably a coagulated albuminoid, it may even prove to be a valuable nitrogenous compound of stock or poultry feed.

The converted liquor was cooled to room temperature and carefully neutralized by lime to slight alkalinity $\left(\mathrm{P}_{\mathrm{B}} 7.5\right.$ to 8.0$)$. The exact reaction to be attained is undoubtedly of considerable importance and will be subjected to further investigation in subsequent experiments in connection with the problems of filtration. All filtrations were made on 7-inch Büchner funnels by suction and for laboratory operation were sufficiently rapid. It is probable that on a larger installation conversion, defecation, and filtration can be carried out more effectively at high temperatures.

The resulting juice was perfectly clear, but somewhat darker than is obtained in beet juice clarification. It changed markedly, however, with the reaction of the solution, being darkest in neutral solution, considerably lighter in acid solution, while in the alkaline medium of the precipitation process, to be described later, it assumed a very light straw yellow color. 


\section{CONVERSION}

In addition to the substances of the inulin group, the juices of the artichoke contain relatively small quantities of sucrose which, for the purposes of the present work, must be inverted. The conversion process must, therefore, be conducted in such manner that all these various products shall yield the maximum quantity of levulose, with the least danger of destruction of the products of hydrolysis. These conditions are most effectively determined by a study of the chemical kinetics of the conversion reaction. Since the inulins are undoubtedly in a state of colloidal solution and not in physical suspension, it is evident that we are dealing with a homogeneous system.

For a determination of the reaction velocity $175 \mathrm{cc}$ of juice, heated and maintained at $79.8^{\circ} \mathrm{C}$., was acidified with $2.0 \mathrm{cc}$ of 8.473 $\mathrm{N} \mathrm{H}_{2} \mathrm{SO}_{4}$. The resulting mixture was thus somewhat less than tenth normal with respect to sulphuric acid, an undetermined portion of the acid being neutralized by the inorganic constituents of the juice. At appropriate intervals of time portions were removed and polarized. The results are assembled in Table 4. It is apparent from column 5 that the resultant of the various reactions occurring during the conversion process follows substantially the course of a unimolecular reaction, and we may compute the time required for complete conversion by simple algebraic transformation.

TABLE 4.-Velocity of conversion of artichoke juices by $0.1 \mathrm{~N} \mathrm{H}_{2} \mathrm{SO}_{4}$ at $80^{\circ} \mathrm{C}$.

\begin{tabular}{|c|c|c|c|c|}
\hline Time in minutes & $\begin{array}{l}\text { Rotation } \\
\text { observed }\end{array}$ & $R_{t}-R \infty$ & $\log \frac{R_{0}-R \infty}{R_{\mathrm{t}}-R \infty}$ & $k=\frac{1}{t} \log \frac{R_{0}-R \infty}{R_{t}-R \infty}$ \\
\hline $\begin{array}{l}{ }^{9}{ }^{9} \\
19.5 \\
31.0 \\
39.5 \\
52.0 \\
71.0 \\
81.0\end{array}$ & $\begin{array}{l}+0.08 \\
-6.80 \\
-12.30 \\
-16.80 \\
-19.03 \\
-21.63 \\
-23.60 \\
-24.25 \\
-26.51\end{array}$ & $\begin{array}{r}19.71 \\
14.21 \\
9.71 \\
7.48 \\
4.88 \\
2.91 \\
2.26\end{array}$ & $\begin{array}{r}0.1294 \\
.2716 \\
.4375 \\
.5503 \\
.7358 \\
.9605 \\
1.0701\end{array}$ & $\begin{array}{r}0.0136 \\
.0139 \\
.0141 \\
.0139 \\
.0141 \\
.0135 \\
.0132 \\
\end{array}$ \\
\hline Mean & & & & .0137 \\
\hline
\end{tabular}

In Table 5 are given the velocity constants of the reaction under varying conditions of acidity and temperature. In general practice the velocities will vary considerably with the composition and concentration of the juice. Thus, solution $(c)$ in Table 5 possessed a higher concentration of solids than solutions $(a)$ and $(b)$, as illustrated by the final rotations, $R \infty$. Consequently, a greater amount of acid was rendered ineffective by the inorganic impurities and the velocity constants for given strengths of acid are lower. It will undoubtedly be possible to predict with satisfactory accuracy the velocity constants for the respective acidities as a function of the concentration of the solution measured either by density or rotary power. The 
data presented here, however, serve to show the order of magnitude of the velocity constants. In a large-scale operation it will be found feasible to devise some method of continuous control of the conversion. This could, for example, take the form of a series of rapid polariscopic readings or some other significant physical property, such as viscosity.

At the completion of the conversion the solution was neutralized by lime for the double purpose of removing the sulphuric acid and accomplishing the defecation. The neutral filtrate is at this point ready for the isolation of the levulose in the form of the lime levulate. The discussion of this process, which may be applied to any crude levulose juice from any source, will be deferred to a later section of this paper.

TABLE 5.-Velocities of conversion of artichoke juices under varying conditions of acidity and temperature

[The "apparent" acidities are those which would have been produced in pure water. A portion of the acid in each instance was rendered ineffective by inorganic impurities]

[ $R_{\circ}$, initial rotation; $R_{\infty}$, rotation at completion of conversion]

(a) $R_{0}+0.08 \quad R_{\infty}-26.43$

\begin{tabular}{|c|c|c|}
\hline Temperature $\left({ }^{\circ} \mathrm{C}.\right)$ & $\begin{array}{l}\text { Acidity (appar- } \\
\text { ent) normality }\end{array}$ & $\begin{array}{l}\text { Velocity } \\
\text { constant }\end{array}$ \\
\hline $\begin{array}{l}79.8 \\
79.8 \\
78.2\end{array}$ & $\begin{array}{l}0.10 \mathrm{H}_{3} \mathrm{SO}_{4} \\
.20 \mathrm{H}_{3} \mathrm{SO}_{4} \\
.10 \mathrm{HCl}\end{array}$ & $\begin{array}{r}0.0137 \\
.0788 \\
.0381\end{array}$ \\
\hline
\end{tabular}

(b) $R_{0}-2.40 \quad R_{\infty}-25.88$

\begin{tabular}{|c|c|c|}
\hline 99.0 .0 & $\begin{array}{l}0.0294 \mathrm{HCl} \\
.0516 \mathrm{HCl} \\
.0667 \mathrm{HCl}\end{array}$ & $\begin{array}{l}0.00327 \\
.02737 \\
.1371\end{array}$ \\
\hline
\end{tabular}

(c) $R_{0}-1.29 \quad R_{\infty}-34.48$

\begin{tabular}{|c|c|c|}
\hline 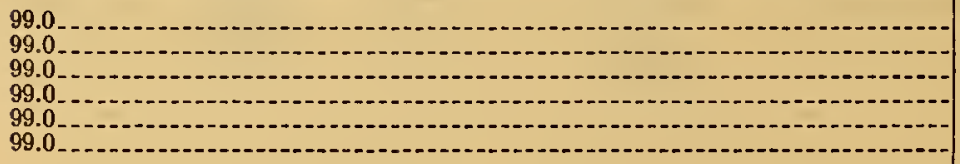 & $\begin{array}{l}0.0240 \mathrm{HCl} \\
.0462 \mathrm{HCl} \\
.0571 \mathrm{HCl} \\
.0676 \mathrm{HCl} \\
.0773 \mathrm{HCl} \\
.1041 \mathrm{HCl}\end{array}$ & $\begin{array}{l}0.0010 \\
.00593 \\
.0163 \\
.0353 \\
.0707 \\
.3172\end{array}$ \\
\hline
\end{tabular}

\section{DAHLIAS}

\section{DESCRIPTION}

The dahlia is a hardy plant indigenous to Mexico but capable of cultivation in practically all parts of the United States. The multitude of familiar varieties has been derived by the hybridization of a relatively small number of early forms. ${ }^{19}$ The variability which is so evident in the blossom is equally apparent in the tubers, for there exist great differences in the size and number of tubers accompanying

10 W. E. Safford, "Notes on the genus Dablia," Jour. Wash. Acad., 9, p. 364; 1919. 
each variety of plant. This suggests that the process of artificial selection should be fruitful in developing varieties which may produce tubers of greatly increased size and inulin content. There are even now large-rooted varieties which could be utilized satisfactorily for the production of levulose even without further development.

Through the courtesy of Richard Vincent, jr., of White Marsh, Md., we have had an adequate supply of dahlia tubers for the purposes of analysis and levulose extraction. It is a pleasure to acknowledge our great indebtedness to Mr. Vincent for his generous cooperation. We have also received tubers from Mrs. G. M. Wolfe, of Forest Glen, Md., whom we take this opportunity to thank for her courtesy. In addition we have obtained by purchase a number of specially named varieties which unfortunately were received in a seriously deteriorated condition.

While we have secured no data on the tonnage or cost of dahlias per a cre, we are assured by Mr. Vincent that it would be possible to propagate large-rooted varieties at low expense and obtain very large yields of tubers. The dahlia can be propagated from seeds, or from numerous cuttings from a parent plant, or by dividing the groups of tubers and planting one or more "eyes" to a hill.

\section{ANALYTICAL RESULTS}

The extraction of the dahlia juices was accomplished in the manner described for the artichokes. The tubers were in each case received and analyzed during the autumn or early winter. The estimation of total solids was made by use of a Brix hydrometer which, as we have previously shown, but approximately indicates the true solids. Solid substance and purities are consequently "apparent."

The analytical data are presented in Table 6. The varieties designated Capstan, Silvia, and James Vick had seriously deteriorated before extraction. Levulose purities are seen to be considerably higher than those of artichoke juices.

TABLE 6.-Analyses of dahlia tubers

[Percentages are based on original weight of tubers]

\begin{tabular}{|c|c|c|c|c|c|c|c|}
\hline & $\begin{array}{c}\text { Total } \\
\text { solids } \\
\text { ex- } \\
\text { tracted }\end{array}$ & $\begin{array}{l}\text { Levu- } \\
\text { lose }\end{array}$ & $\begin{array}{l}\text { Levu- } \\
\text { lose } \\
\text { purity }\end{array}$ & & $\begin{array}{c}\text { Total } \\
\text { solids } \\
\text { ex- } \\
\text { tracted }\end{array}$ & $\begin{array}{l}\text { Levu- } \\
\text { lose }\end{array}$ & $\begin{array}{l}\text { Levu- } \\
\text { lose } \\
\text { purity }\end{array}$ \\
\hline $\begin{array}{l}\text { Miseellaneous roots of } \\
\text { large size. } \\
\text { Thin elongated roots } \\
\text { Miscellaneous. } \\
\text { Lady Thornhill }\end{array}$ & $\left\{\begin{array}{c}\text { Per cent } \\
16.16 \\
17.96 \\
17.7 \\
15.4 \\
16.8\end{array} \mid\right.$ & $\begin{array}{c}\text { Per cent } \\
12.44 \\
11.0 \\
14.05 \\
12.0 \\
12.15\end{array}$ & $\begin{array}{c}\text { Percent } \\
76.9 \\
61.2 \\
79.4 \\
78.0 \\
79\end{array}$ & $\begin{array}{l}\text { James Vick } \\
\text { Patrick O'Mara. } \\
\text { Yellow Duke } \\
\text { Rose Pink Century. }\end{array}$ & \begin{tabular}{|} 
Per cent \\
14.4 \\
13.95 \\
12.9 \\
18.25
\end{tabular} & $\begin{array}{r}\text { Per cent } \\
9.75 \\
10.45 \\
9.32 \\
13.65\end{array}$ & $\begin{array}{r}\text { Per cent } \\
67.8 \\
75.0 \\
72.2 \\
74.8\end{array}$ \\
\hline $\begin{array}{l}\text { Capstan } \\
\text { Silvia. }\end{array}$ & $\begin{array}{l}16.3 \\
14.7\end{array}$ & $\begin{array}{r}13.16 \\
9.43\end{array}$ & $\begin{array}{l}80.6 \\
64.1\end{array}$ & Average & 15.9 & 11.6 & 72.9 \\
\hline
\end{tabular}

$61308^{\circ}-26 \dagger-3$ 


\section{DEFECATION}

The juice of the dahlia tuber is relatively rich in the levulose derivative known as inulin, which is the only one of these condensed forms that possesses a low solubility in cold water and which may be readily isolated. The treatment of dahlia juices may, therefore, differ from that of artichoke juices in that a considerable portion of the levulose may be obtained in the form of inulin before conversion.

The extracted juices may be very simply prepared for the separation of inulin. For many purposes a simple filtration with kieselguhr at 80 to $90^{\circ} \mathrm{C}$. yields a juice from which very nearly white inulin may be crystallized. A method of defecation has been described by Daniel ${ }^{20}$ in patent literature. In his procedure the juice is heated to $80^{\circ} \mathrm{C}$. for one-half to one and one-half hours in the presence of an excess of sodium carbonate, the duration of heating and amount of carbonate being determined by observing whether further treatment produces a further precipitation of impurities. We have not had opportunity to examine this method in detail, but have observed that the addition of sodium carbonate causes a copious precipitation of impurities. We have, moreover, determined that no decomposition of carbohydrates occurs during the period of heating prescribed.

Whether any practical advantage accrues from the application of Daniel's procedure is not as yet apparent. If simple filtration with kieselguhr produces inulin of equal whiteness and purity, evidently a more elaborate process is unnecessary. In any event the filtrate from the inulin separation will contain levulins which must be converted and defecated for the recovery of levulose. On account of the relatively high alkalinity of the filtrate, Daniel's process offers the disadvantage that excessive amounts of acid must be employed to convert the liquors.

\section{SEPARATION OF INULIN}

From the defecated filtrate inulin crystallizes upon cooling. From a consideration of the low solubility of inulin it was to be expected that the separation would be very nearly quantitative. This, however, proved not to be the case with such juices as were available for these experiments. The quantity of inulins which was recovered appeared to be extremely variable and to depend not only on the condition and variety of dahlias, but upon the method employed to induce crystallization. Thus, if the juice was cooled by standing on ice over night frequently as low as $60 \mathrm{per}$ cent of the inulins crystallized, while by freezing the entire mass and allowing it to thaw amounts varying from 66 to 85 per cent were recovered. It was

${ }^{20}$ U. S. Patent No. 1399544, Dec. 6, 1921. 
apparent either that the nonsugars increased the solubility of inulin or that many of the condensation products of higher solubility were present. That the latter supposition is the correct one was shown by the fact that the wash water used to wash the inulin carried large quantities of the levulins, amounting sometimes to more than 10 per cent of the total content of the juice. Dean ${ }^{21}$ in a study of the properties of inulin found, similarly, that dahlia juices contained levulins.

Of the various condensation products of levulose which are encountered in plant juices inulin yields a converted liquor of highest levulose purity. This becomes apparent by inspection of Table 1, which shows the specific rotation of the converted liquors and the ratio of dextrose to levulose in inulin and the levulins, respectively, as determined by Tanret.

For the purpose of obtaining a converted liquor from which levulose can be crystallized purities are of paramount importance. It follows, therefore, that as far as possible the inulin should be uncontaminated by levulins. In the earlier experiments, before the importance of this fact was realized, the extractions were conducted in such manner as to obtain the maximum yields of inulins. In every such instance the purities of the resulting product were after conversion relatively low and, in general, varied between 82 and 76 per cent.

Owing to the variability in composition of dahlia juices it is impossible to specify such densities and temperatures as will yield the purest inulin. In general, the juices should be diluted as much as is desirable during the extraction of the tubers by liberal quantities of maceration water. They are then heated to 90 to $100^{\circ} \mathrm{C}$., treated with kieselguhr, filtered, and allowed to cool. In the neighborhood of 20 to $30^{\circ} \mathrm{C}$. inulin appears as a finely divided precipitate which, behaving like a crystalline substance, becomes granular if allowed to form slowly and with gentle agitation. In most instances it is advantageous to cool to 0 to $10^{\circ} \mathrm{C}$. in order to complete the inulin separation.

The inulin thus obtained is sufficiently granular to filter very readily and may be washed with cold water. It is advisable to employ liberal quantities of cold wash water, since inulin itself has a low solubility and it is desirable to remove the levulins as completely as possible. The wash water may be used for maceration during subsequent extractions of tubers.

These results may be illustrated by a typical extraction. The inulin was crystallized at about $6^{\circ} \mathrm{C}$., filtered, and washed. The con-

${ }^{21}$ Am. Chem. Jour., 32, p. 78; 1904. 
verted liquors had an apparent purity of 86.1 per cent. The filtrate, after being completely frozen and thawed, yielded an additional quantity of inulins which, after conversion, possessed a purity of but 80 per cent.

It has appeared that the more completely the inulin is freed from the levulins the higher the purity of the converted liquor becomes. In order to ascertain how high a purity can be reached by elaborate purification, a quantity of inulin was recrystallized three times from aqueous solution. The purified material was then converted by $0.2 \mathrm{~N}$ sulphuric acid by agitating the mixture for about 10 days at $30^{\circ} \mathrm{C}$. After removal of the sulphuric acid by barium carbonate the converted liquor was found to have an apparent purity of 90.2 per cent. It is of interest to note that this is approximately the maximum dextrose purity which can be attained by the acid hydrolysis of starch. By a single crystallization of inulin from the raw dahlia juices we obtained upon conversion liquors of 86 purity, and it may be concluded, in general, that the liquors which can be obtained directly by conversion of inulin will possess purities varying between 85 and 90 per cent. It will be shown below that such sirups will readily deposit crystalline levulose of high purity.

\section{CONVERSION OF PURE INULIN}

The conversion of inulin is readily accomplished by heating with dilute acids. In a previous section it has been shown that the conversion reaction of the mixed inulin and levulins occurring in artichoke juices follows the course of a unimolecular reaction. It now remains to examine the kinetics of purified inulin. For this purpose the recrystallized and washed inulin was employed while in the form of a thick paste. It was found to be particularly advantageous to use the paste because the dried inulin dissolved very slowly. The paste contained 34 per cent dry substance and had an approximate density of 1.15 .

A mass of $76.5 \mathrm{~g}$ of inulin paste was heated in an Erlenmeyer flask by immersion in boiling water. When the paste became quite fluid, it was acidified with 1 cc of $0.634 N \mathrm{HCL}$ to supply a resulting acidity of $0.0094 N$. Since the recrystallized inulin contained inorganic impurities, the effective acidity was somewhat lower. At suitable intervals of time portions of the mixture were withdrawn and polarized. Table 7 shows the results of these measurements. In the final column are given the values of the velocity constant on the assumption that the reaction is of the first order. Although the results are discordant, no systematic deviations are observable. 
TABLE 7.-Velocity of conversion of inulin at $100^{\circ} \mathrm{C}$. in the presence of $0.0094 \mathrm{~N}$

[Since a portion of the acid was rendered inactive by inorganic impurities, the effective acidity was unknown $\left.R_{0}-R_{\infty}=56: 60\right]$

\begin{tabular}{|c|c|c|c|}
\hline Time in minutes & $\begin{array}{l}\text { Polari- } \\
\text { zation } R \\
\text { sugar } \\
\text { degrees }\end{array}$ & $\frac{R_{0}-R_{\infty}}{R_{\mathrm{t}}-R_{\infty}}$ & $k=\frac{1}{t} \log \frac{R_{0}-R_{\infty}}{R_{t}-R_{\infty}}$ \\
\hline $\begin{array}{l}0.67 \\
13.9 \\
19.47\end{array}$ & $\begin{array}{l}-31.65 \\
-35.68 \\
-42.18 \\
-46.22\end{array}$ & $\begin{array}{l}1.0767 \\
1.2286 \\
1.3466\end{array}$ & $\begin{array}{r}0.00568 \\
.00642 \\
.00664\end{array}$ \\
\hline 40.83 40.93 & $\begin{array}{l}-48.16 \\
-52.22 \\
-59.58 \\
-88.25\end{array}$ & $\begin{array}{r}1.4118 \\
1.5709 \\
1.9742 \\
\end{array}$ & $\begin{array}{r}.00602 \\
.00647 \\
.00724 \\
\end{array}$ \\
\hline Mean & & & .00641 \\
\hline
\end{tabular}

In Table 8 are shown similar velocity constants at varying concentrations of acid. By taking the differences between the constants at the varying acidities we may eliminate arithmetically the neutralizing influence of the ash and arrive at an approximate velocity of conversion of ash-free inulin. From the mean of these calculations it may be concluded that $0.01 \mathrm{~N} \mathrm{HCl}$ converts ash-free inulin at $100^{\circ} \mathrm{C}$. with a velocity of about 0.020 . Under similar conditions cane sugar is inverted with a velocity of about 0.27 . In other words, inulin is more than thirteen times as resistant to hydrolytic action as cane sugar. These considerations may ultimately be significant as an aid in determining the mode of linkage of levulose in the inulin molecule.

TABLE 8.-Velocity of conversion of inulin in the presence of varying concentrations of hydrochloric acid at $100^{\circ} \mathrm{C}$.

[By taking the differences in velocity at the higher acidities the neutralizing action of inorganic impurities is arithmetically eliminated]

\begin{tabular}{|c|c|c|c|}
\hline & Normality of $\mathrm{HCl} N$ & $\begin{array}{c}\text { Velocity } \\
\text { constant } \\
V\end{array}$ & $\begin{array}{l}\text { Velocity (ash-free) } \\
\text { in } 0.01 \mathrm{HCl}\end{array}$ \\
\hline 1 & 0.0095 & 0.00641 & $\left\{\quad \frac{V(3-2)}{N(3-2)}=0.0184\right.$ \\
\hline 2 & $0.0199 \ldots$ & .0394 & $\frac{V(4-3)}{N(4-3)}=0.0212$ \\
\hline 3 & 0.0545 & . 1022 & $\frac{V(4-2)}{N(4-2)}=0.0199$ \\
\hline \multirow[t]{2}{*}{4} & 0.1034 & .2057 & - \\
\hline & Mean_- - & & 0.020 \\
\hline
\end{tabular}

\section{DECOMPOSITION OF LEVULOSE IN ACID SOLUTION}

Under any conditions of acidity and temperature which are necessary for the conversion of the inulins levulose probably suffers more or less destruction. Since the optimum conditions for rapid conversion and least decomposition will ultimately require an exhaustive 
study, the experiments cited here serve only to illustrate the type of experiment which must eventually be undertaken in detail. Table 9 shows the effects of sulphuric acid at 100 and $70^{\circ} \mathrm{C}$., respectively, on the polarization of pure levulose in aqueous solution.

TABLE 9.-The decomposition of levulose in the presence of sulphuric acid

\begin{tabular}{|c|c|c|c|}
\hline $\begin{array}{l}\text { Tempera- } \\
\text { ture }\left({ }^{\circ} \mathrm{C} .\right)\end{array}$ & $\begin{array}{l}\text { Time in } \\
\text { minutes }\end{array}$ & $\begin{array}{c}\text { Acidity } \\
\text { normality }\end{array}$ & $\begin{array}{l}\text { Polariza- } \\
\text { tion in } \\
\text { saccha- } \\
\text { rimeter, } \\
\text { degrees }\end{array}$ \\
\hline $\begin{array}{l}100 \\
100 \\
100 \\
100\end{array}$ & $\begin{array}{l}15 \\
30 \\
15 \\
30\end{array}$ & $\begin{array}{l}0.0304 \\
.0304 \\
.0584 \\
.0584\end{array}$ & $\begin{array}{r}186.25 \\
83.70 \\
82.90 \\
83.30 \\
81.16\end{array}$ \\
\hline $\begin{array}{l}70 \\
70 \\
70 \\
70\end{array}$ & $\begin{array}{l}15 \\
30 \\
15 \\
30\end{array}$ & $\begin{array}{l}.0474 \\
.0474 \\
.0891 \\
.0891\end{array}$ & $\begin{array}{r}185.89 \\
85.87 \\
85.63 \\
85.79 \\
85.26\end{array}$ \\
\hline
\end{tabular}

1 Control solution.

\section{THE LIME PRECIPITATION PROCESS}

In previous sections methods have been described for obtaining levulose-containing juices from various sources. Some of these juices will contain levulose in a sufficiently high state of purity to permit the direct crystallization of the sugar. Such, for example, are the juices obtained by the conversion of pure inulin or those obtained from the varieties of artichokes which exhibit a high ratio of levulose to total sugars and a low content of nonsugars. Many other juices will have too low a purity to permit a ready crystallization of levulose. From such juices the levulose can be recovered in the form of its insoluble compound with lime. The present section of this paper is concerned with the separation of levulose from solutions of low purity derived from any source whatever.

\section{HISTORICAL}

In 1847 Dubrunfaut ${ }^{22}$ announced that from invert sugar one of the components could be isolated as an insoluble calcium salt. In $1856 \mathrm{he}^{23}$ announced the conclusion that invert sugar was composed of two sugars, one of them being glucose, the other being identical with the sugar hitherto prepared from inulin. In 1869 he ${ }^{2 t}$ described his method in detail. To $100 \mathrm{cc}$ of a solution containing $10 \mathrm{~g}$ of inverted sucrose he added at a low temperature $6 \mathrm{~g}$ of finely powdered calcium hydroxide with vigorous agitation. The calcium compound appeared as a milky precipitate which was 
separated from the dextrose by filtration and washing. It was suspended in water and decomposed with oxalic, sulphuric, or carbonic acid. He was, however, unable to obtain the sugar in crystalline form.

Dubrunfaut's procedure has persisted with but slight modification to the present day, and while it may be utilized for laboratory preparations, it is impracticable for industrial production.

In preliminary experiments it was observed that by the mode of procedure of Dubrunfaut and subsequent workers ${ }^{25}$ the precipitate of lime levulate ${ }^{26}$ appears as a finely divided suspension which filters with great difficulty. For industrial requirements it was obviously necessary to seek some method of improving the physical character of this compound. Consequently, attention was turned to the preparation and properties of this compound. ${ }^{27}$

\section{PROPERTIES OF LIME LEVULATE}

A series of experiments was performed in which the lime compound was allowed to precipitate in $50 \mathrm{cc}$ bottles kept in motion in ice water at a mean temperature of about $1^{\circ} \mathrm{C}$. At the conclusion of the reaction the mass was filtered through asbestos in an apparatus immersed in ice water. The following experiments were designed to show the solubility of the lime compound, its composition, and the influence of dextrose on its solubility. In the first three experiments the lime was weighed and slaked in the bottle and the sugar added. thereto.

1. One gram of pure levulose and $1 \mathrm{~g}$ of $\mathrm{CaO}$ previously slaked were agitated in a volume of $50 \mathrm{cc}$. After agitation for about a half hour a portion of the filtrate was titrated with standard acid and another weighed portion after neutralization was polarized. The filtrate contained $0.144 \mathrm{~g}$ of $\mathrm{CaO}$ in $100 \mathrm{cc}$ and 0.115 per cent of levulose.

2. One gram of pure levulose and $2 \mathrm{~g}$ of $\mathrm{CaO}$ were agitated in a similar manner for one hour. The filtrate contained $0.147 \mathrm{~g}$ of $\mathrm{CaO}$ in $100 \mathrm{cc}$ and 0.119 per cent levulose.

The practically identical composition of these two filtrates indicated, in accordance with the phase rule, a quadruple point at $1^{\circ} \mathrm{C}$.

23 Summarized by Farding, Sugar, 25, p. 406; 1923.

26 The term "levulate" is suggested for the sake of euphony and in correspondence with the common appellation "saccharate" which is applied to the lime precipitate in the beet-sugar industry.

${ }^{27} \mathrm{It}$ is interesting to note that levulose and the compound sugars of the sucrose group form characteristic insoluble compounds with one or more of the alkaline earths. Thus, sucrose forms insoluble barium, strontium, and calcium compounds; levulose and raffinose form insoluble lime compounds; stachyose is known to form an insoluble strontium compound, and verbascose an insoluble barium compound. It is conceivable that this characteristic is due to the presence of the levulose rcsidue, and we may possibly predict that since gentianose belongs to the sucrose group it may likewise form an insoluble alkaline earth compound, which fact would undoubtedly aid in its extraction. 
at which the solid phases were lime and lime levulate. Consequently, there was an excess of lime in both cases.

3. Two grams of levulose and $1 \mathrm{~g}$ of $\mathrm{CaO}$ were permitted to react in a similar manner. The filtrate contained $0.089 \mathrm{~g}$ of $\mathrm{CaO}$ per 100 cc and 0.346 per cent of levulose.

4. Three grams of pure levulose were dissolved in about $45 \mathrm{cc}$ of water, and small additions of slaked lime were made until there remained no doubt that a slight permanent precipitation of the lime compound had occurred. In general, the lime dissolved rapidly to form a clear solution from which finally the levulate precipitated suddenly, leaving no doubt of its formation. The lime was added in such a manner that there was present a great excess of levulose. Both filtrate and solid phase were analyzed. Since the precipitate was uncontaminated with an excess of lime, its analysis fairly represented the composition of the compound. The filtrate contained $0.684 \mathrm{~g}$ of $\mathrm{CaO}$ per $100 \mathrm{cc}$ and 4.65 per cent of levulose. The solid phase contained $0.3193 \mathrm{~g}$ of $\mathrm{CaO}$ and $1.055 \mathrm{~g}$ of levulose. The ratio of levulose to $\mathrm{CaO}$ in the solid phase is thus 3.02 ; the calculated ratio, assuming the formula $\mathrm{C}_{6} \mathrm{H}_{12} \mathrm{O}_{6}$. $\mathrm{CaO}$, is 3.11 . The compound is, therefore, a monocalcium levulate, probably hydrated.

The formula $\mathrm{C}_{8} \mathrm{H}_{12} \mathrm{O}_{6} .3 \mathrm{CaO}$ was originally stated by Dubrunfaut to represent this compound. Later workers, ${ }^{28}$ Winter, Peligot, and Herzfeld, however, obtained the monobasic compound which was found in the present investigation.

It is of interest to note that the filtrates from experiments 1 and 2 contained a lower ratio of levulose to lime and experiment 3 a higher ratio than is represented by the formula. The compound is then stable in the presence of an excess of either constituent, and consequently stable in contact with solutions of its own composition.

The filtrate from experiment 4 possessed an alkalinity four times as great as those from experiments 1 and 2 in spite of the great deficiency of added lime. The greater alkalinity evidently was caused by the excess levulose and confirms Peligot's conclusion ${ }^{28}$ that the presence of levulose in solution increases markedly the solubility of the lime compound.

A series of experiments was carried out in which the precipitation of the lime levulate occurred in the presence of varying concentrations of dextrose. The results are assembled in Table 10. These experiments, although rendered crude by the uncertainties of the analytical methods, show that the solubility of lime levulate is roughly proportional to the concentration of dextrose in solution.

${ }^{28} \nabla$. Lippman, Die Chemie der Zuckerarten, 1, p. 881; 1904.

29 v. Lippmann, Die Chemie der Zuckerarten, 1, p. 882; 1904. 
TABLI 10.-Analyses of filtrates from precipitations of levulate from invert sugar solutions of various concentrations

\begin{tabular}{|c|c|c|}
\hline $\begin{array}{c}\text { Dextrose, } \\
\text { grams per } \\
100 \mathrm{cc}\end{array}$ & $\begin{array}{c}\text { Levulose, } \\
\text { grams per } \\
100 \mathrm{cc}\end{array}$ & $\begin{array}{c}\mathrm{CaO}, \\
\text { grams per } \\
100 \mathrm{cc}\end{array}$ \\
\hline 0 & 0.116 & 0.145 \\
1.44 & .434 & .55 \\
2.87 & .505 & -.1 .02 \\
3.59 & .615 & 1.60 \\
4.55 & .81 & 1.48 \\
5.95 & .91 & 2.34 \\
8.95 & - & \\
\hline
\end{tabular}

\section{THE PRECIPITATION OF LIME LEVULATE}

The precipitation of lime levulate from invert sugar solutions was at first carried out by the methods described by Dubrunfaut and subsequent authors. To the invert sugar cooled to 5 to $0^{\circ} \mathrm{C}$. was added a slaked lime paste and the mixture agitated violently. The precipitation occurred rapidly and abundantly, but the resulting mixture filtered so slowly that the methods were judged unsatisfactory. The unsatisfactory filtration was undoubtedly due to the physical condition of the precipitate, which consisted of vast numbers of minute particles offering great resistance to the flow of the waste water. An effort was made to produce a granular precipitate by adding the lime slowly and permitting the crystals to develop. During the process the mixture was frequently seeded with the levulate prepared in a small batch by the methods already in vogue. There occurred, however, the same phenomena that have already been described. In the presence of the relatively high concentration of both dextrose and levulose, not only the lime but the lime levulate acquired a high solubility, and consequently both the lime and the seed dissolved without the production of a precipitate. When the concentration of lime became high enough to cause a great supersaturation of the levulate, the precipitation occurred suddenly and yielded a paste nearly as difficult to filter as those produced by the published methods. However, after several trials it was found possible to obtain a granular mixture by seeding abundantly at moments before a great supersaturation had been reached. In these trials the precipitated levulate filtered readily and was washed rapidly with iced limewater. On carbonation of the levulate cake, however, the purity of the levulose was found to have suffered greatly. In some instances a sirup was obtained of a purity of but 80 to 85 per cent. The defects in the procedure were then clearly apparent. The solution of lime in the early stages of the reaction produced a high alkalinity which reached a maximum before the precipitate appeared and in the presence of the sugars at their highest concentration. Under such conditions the familiar destructive action of the alkali upon reducing sugars proceeded rapidly 
and caused not only a loss of levulose but a contamination of the precipitate.

The requirements which must be satisfied by the procedure then became evident. First, the levulate precipitate must be granular in order to permit a ready separation of waste water by ordinary filtration methods. Such a precipitate was secured by promoting the growth of the levulate crystals from constant accretions of newly formed levulate, which was induced to deposit on crystals already present rather than to form new crystals. Secondly, the soluble alkalinity of the solution must be kept at its minimum. As we have seen above, lime is readily dissolved by solutions of either dextrose or levulose. Consequently, the minimum solution of lime occurs if the concentration of sugar is kept at its minimum. While we can not influence the concentration of dextrose during the precipitation process, we can aroid the solvent effect of levulose by insuring the immediate precipitation of all that which is present in the reaction mixture. Under these conditions the only considerable alkalinity is caused by the lime which is dissolved by the nonlevulose sugars. The complete precipitation of levulose is accomplished by having present at all times the equivalent quantities of lime and levulose in the reaction mixture. It is obvious that an excess of lime does not increase the alkalinity of the solution unless it is dissolved, and that a slight excess is desirable in order to approximate the quadruple point of the system and thus obtain the maximum precipitation of levulose.

The amount of lime theoretically required is, according to the formula of the compound, about one-third of the weight of levulose taken. There is, however, a portion of the lime which is dissolved by the dextrose, a portion which is unreactive, and probably a portion which is included in the precipitate without undergoing reaction. Consequently, an excess of lime over the theory is required in practice. In general, a quantity of $\mathrm{CaO}$ equal to from 40 to 50 per cent of the levulose present in the crude liquors is required.

The precipitations were conducted in an 8-quart ice-cream freezer, whose cover was perforated in order to receive the additions of lime. A hole was drilled through the shaft of the dasher to receive a tube through which the sugar solution dripped continuously while the contents of the freezer were kept in agitation.

A typical method of procedure which is subject to obvious variation is as follows: Six liters of the levulose-containing solution were contained in a large cylindrical percolator, which was graduated in $100 \mathrm{cc}$ divisions. The tubulature in the bottom was connected with the freezer by a copper tube extending into the hole in the dasher. The flow of solution was regulated by a stopcock.

The slaked lime was diluted with water to a volume of $1,050 \mathrm{cc}$ and was added to the freezer in 15 portions of $70 \mathrm{cc}$ each. One 
portion of lime was thus equivalent to 400 ce of sugar solution. About $500 \mathrm{cc}$ of water and 1 portion of lime were introduced into the freezer and cooled by sparingly salted ice to a temperature of about 1 or $2^{\circ} \mathrm{C}$. The levulose solution was then allowed to drip slowly into the mixture until $400 \mathrm{cc} \mathrm{had} \mathrm{been} \mathrm{added.} \mathrm{At} \mathrm{this} \mathrm{point} \mathrm{another}$ portion of lime was added, and the operation was continued in this manner until the entire amounts of the reactants had been introduced.

The excess of lime insured the most complete precipitation of levulose at all times, and by the manner of procedure each entering portion of reactants became diluted to the whole volume of the mixture then present before undergoing reaction. Since the levulate has an appreciable solubility, its tendency would be rather to precipitate upon nuclei of levulate already present than to form new nuclei. It is in this way that a granular precipitate was produced.

At the completion of the precipitation, which required from 20 to 30 minutes, the levulate was filtered on three 7-inch Büchner funnels and was washed with iced limewater. Filtration, which required about five to seven minutes, yielded a cake which after pressing with a spatula was from $3 / 4$ to 1 inch thick. Washing was continued until the filtrate showed no discoloration. This required from 10 to 15 minutes.

The cake was weighed, suspended in iced water, and carbonated by means of a Doherty carbonator, ${ }^{30}$ care being taken to avoid a rise in temperature by small additions of chopped ice. The calcium carbonate was removed by filtration and thoroughly washed. The filtrate, which was in most instances nearly water white, while in dilute solution was concentrated in a vacuum for the crystallization of levulose.

TABLE 11.-The precipitation of lime levulate from artichoke juices

\begin{tabular}{|c|c|c|c|c|c|c|c|c|}
\hline Experiment number & $\begin{array}{l}\text { Levulose } \\
\text { taken }\end{array}$ & $\begin{array}{l}\text { Avail- } \\
\text { able } \\
\text { CaO }\end{array}$ & $\begin{array}{c}\text { Ratio: } \\
\text { CaO } \\
\text { levulose }\end{array}$ & $\begin{array}{c}\text { Weight, } \\
\text { washed } \\
\text { cake }\end{array}$ & $\begin{array}{c}\text { Volume } \\
\text { filtrate } \\
\text { and } \\
\text { washings }\end{array}$ & $\begin{array}{l}\text { Alka- } \\
\text { linity of } \\
\text { filtrate }\end{array}$ & $\begin{array}{l}\text { Levulose } \\
\text { re- } \\
\text { covered }\end{array}$ & $\begin{array}{l}\text { Appar- } \\
\text { ent } \\
\text { purity } \\
\text { of sirup }\end{array}$ \\
\hline & $\begin{array}{l}9 \\
476.0 \\
560.4 \\
538.0 \\
309.8 \\
446.6\end{array}$ & $\begin{array}{r}g^{\circ} \\
248 \\
257 \\
247 \\
146 \\
208\end{array}$ & $\begin{array}{l}0.52 \\
.46 \\
.46 \\
.47 \\
.47\end{array}$ & \begin{tabular}{c}
$g$ \\
\hdashline 2,137 \\
\hdashline, 282
\end{tabular} & $\begin{array}{l}c c \\
6,540 \\
6,670 \\
7,527\end{array}$ & $\begin{array}{c}\begin{array}{c}\text { g } \mathrm{CaO} \\
\text { in } 100 \mathrm{cc}\end{array} \\
1.035 \\
.698 \\
.762\end{array}$ & $\begin{array}{c}\text { Per cent } \\
82.55 \\
85.6 \\
87.7 \\
82.0 \\
90.6\end{array}$ & $\begin{array}{r}\text { Per cent } \\
95.78 \\
91.70 \\
93.63 \\
95.73 \\
97.21\end{array}$ \\
\hline $\begin{array}{l}6-- \\
7--- \\
8--- \\
9-.-\end{array}$ & $\begin{array}{l}499.1 \\
419.7 \\
471.0 \\
471.0\end{array}$ & $\begin{array}{l}230 \\
195 \\
217 \\
176\end{array}$ & $\begin{array}{l}.46 \\
.46 \\
.46 \\
.37\end{array}$ & $\begin{array}{l}1,974 \\
1,970 \\
1,738\end{array}$ & $\begin{array}{l}7,210 \\
7,245\end{array}$ & .662 & $\begin{array}{l}82.8 \\
81.2 \\
83.2 \\
82.2\end{array}$ & $\begin{array}{l}91.72 \\
94.14 \\
95.74 \\
94.75\end{array}$ \\
\hline $\begin{array}{l}10 \\
11- \\
12- \\
13 .\end{array}$ & $\begin{array}{l}471.0 \\
499.6 \\
499.6 \\
508.0\end{array}$ & $\begin{array}{l}195 \\
207 \\
207 \\
211\end{array}$ & $\begin{array}{l}.41 \\
.41 \\
.41 \\
.41\end{array}$ & $\begin{array}{l}1,899 \\
1,854 \\
2,006 \\
1,907\end{array}$ & $\begin{array}{l}7,195 \\
6,870 \\
6,654 \\
7,093\end{array}$ & .712 & $\begin{array}{l}90.6 \\
84.1 \\
87.1 \\
85.3\end{array}$ & $\begin{array}{l}91.34 \\
93.43 \\
91.86 \\
91.72\end{array}$ \\
\hline A verag & & & & & & & 85.0 & 93. 75 \\
\hline
\end{tabular}

${ }^{30}$ B. S. Sci. Paper No. 432, 17, p. 603; 1922. 
Typical precipitation data are illustrated in Table 11. The data on levulose taken were obtained by the method of temperature coefficients. Apparent purity of the final sirup was the direct polarization of the sirup divided by the total solids determined densimetrically. The yield was also "apparent," since it involved the apparent purity. True purities and yields would be higher than the apparent. For these precipitations a uniformly high grade of lime was employed which contained 92 per cent of sugar soluble or available $\mathrm{CaO}$. Although the procedure was nearly uniform with respect to details, the apparent purity of the sirup and the yield of sugar were subject to considerable fluctuation. It is believed that while the principal causes of these apparent fluctuations were the uncertainties of the analytical methods, there are still some undetermined factors which, upon further study; will tend to produce the higher purities and yields more uniformly. The mean values of 93.75 purity and 85.0 per cent yield in the present experiments are, however, probably free from any considerable analytical error and indicate that the precipitation process is satisfactorily efficient. As will appear in a later section of this paper, a sirup of such high purity will permit the ready crystallization of levulose.

It has been indicated above that the presence of dextrose increases the solubility of the calcium levulate as well as the solubility of lime. To the presence of dextrose, which amounted to about 25 per cent of the levulose, must be ascribed the 15 per cent loss of levulose and the relatively high alkalinity of the waste water. Evidently by employing the varieties of artichokes of higher ratio of levulose to total sugars this loss may be greatly diminished. A fermenting organism which would attack dextrose in preference to levulose would render possible a higher extraction from the original juice or a further extraction from the waste water. Furthermore, the presence of alcohol would further diminish the solubility of the levulate. These possibilities will engage our attention in the future.

A number of experiments have been performed on the precipitation from invert sugar and from beet molasses. From the latter a somewhat discolored sirup was obtained of 94 per cent purity. It was found that the discoloration was removed by a small amount of carbon with remarkable completeness. A precipitation from converted inulin yielded a sirup of 98 per cent purity.

\section{CRYSTALLIZATION}

\section{HISTORICAL 31}

Although levulose sirups were prepared from inulin as early as 1843 and from invert sugar in 1847, nearly 40 years elapsed from

31 T. S. Harding, History of Levulose, Sugar, 25, p. 406; 1923. 
these early beginnings before a single crystal of levulose was obtained. In 1880 Jungfleish and Lefrance starting from invert sugar, Kiliani from inulin, and Girard from invert sugar succeeded in inducing crystallization after a nearly complete dehydration of the sirups by repeated extractions with absolute alcohol. This method of crystallization has persisted with slight modification to the present time. Many workers have succeeded in crystallizing the sugar from aqueous alcohol or by use of glacial acetic acid. Inasmuch as our present purpose is to suggest the outline of a method adaptable to an industrial scale of operation and, therefore, to eliminate the use of expensive reagents, these methods must be discarded. A practicable industrial process would then require that the substance be crystallized from aqueous solution. The first step was to ascertain whether the solubility of levulose in water was sufficiently low to justify the expectation of success.

\section{THE SOLUBILITY OF LEVULOSE IN WATER}

A large excess of levulose crystals was agitated in contact with its water solution in a manner which has been previously described in connection with similar solubility determinations. ${ }^{32}$ That equilibrium was established was made evident by duplicate experiments in which the time of agitation was varied. Since the mutarotation of levulose is relatively rapid, a 24-hour period of agitation was found to be sufficient. The time was, however, extended in many instances to several days. The saturated solutions were separated by pressure filtration and analyzed.

The analytical data were obtained by polarization on a saccharimeter and by a determination of the densities of the solutions, both of which methods are involved in some uncertainty. While the results are of adequate precision for the present purpose, they will eventually require revision when the saccharimetric constants and solution densities are known with a higher degree of accuracy than at present.

The data obtained from the solubility experiments are given in Table 12. These results were plotted and connected by as smooth a curve as possible and the solubilities at $5^{\circ}$ intervals were read from this curve. Column 3 shows the weight of levulose dissolved by 100 g of water at the respective temperatures. From the data in the latter column it is apparent that the temperature coefficient of solubility is relatively large. Thus, for a drop of $10^{\circ}$ about 20 per cent of the levulose must crystallize from solution. This suggests that crystallization in a crystallizer by the method of dropping temperatures should be efficient.

${ }^{32}$ Jackson and Silsbee, B. S. Sci. Paper No. 437, 17, p. 716; 1922; B. S. Tech. Paper No. 259, 18, p. 277 ; 1924. 
TABLE 12.-The solubility of levulose in water at various temperatures

[Data in parentheses were experimental results. The remaining data were obtained graphically]

\begin{tabular}{|c|c|c|c|c|c|}
\hline Temperature $\left({ }^{\circ} \mathrm{C}.\right)$ & $\begin{array}{l}\text { Levulose } \\
\text { in satu- } \\
\text { rated } \\
\text { solution }\end{array}$ & $\begin{array}{l}\text { Levulose } \\
\text { in } 100 \mathrm{~g} \\
\text { water }\end{array}$ & Temperature $\left({ }^{\circ} \mathrm{C}.\right)$ & $\begin{array}{l}\text { Levulose } \\
\text { in satu- } \\
\text { rated } \\
\text { solution }\end{array}$ & $\begin{array}{l}\text { Levulose } \\
\text { in } 100 \mathrm{~g} \\
\text { water }\end{array}$ \\
\hline $\begin{array}{l}20 \ldots \\
25 \ldots \\
30 \ldots \\
35 \ldots\end{array}$ & $\begin{array}{c}\text { Per cent } \\
\quad(78.94) \\
80.29 \\
81.64 \\
82.98\end{array}$ & $\begin{array}{l}975 \\
407 \\
445 \\
488\end{array}$ & $\begin{array}{l}40 \\
45 \\
55\end{array}$ & $\begin{array}{c}\text { Per cent } \\
(84.34) \\
85.64 \\
86.90 \\
(88.10)\end{array}$ & $\begin{array}{l}g 39 \\
596 \\
663 \\
740\end{array}$ \\
\hline
\end{tabular}

If the crystallization is so conducted that the final massecuite is centrifuged at a temperature of 20 to $30^{\circ} \mathrm{C}$., it is clear that the mother liquor from solutions of high purity will have a concentration of but 80 to 85 per cent. At these temperatures the viscosity would be considerable for sucrose but is much lower for levulose on account of its smaller molecular weight. ${ }^{33}$

\section{CRYSTALLIZATION PROCEDURE}

The crystallization experiments were performed in small ice-cream freezers operating as crystallizers. The crank was replaced by a large pulley, which, by a system of reducing gears driven by a motor, was made to revolve once in two to three minutes. The crystallizer was inclosed in a large insulated air bath heated by electric lamps. An approximate relation between energy input and temperature having been determined previously, it was possible to drop the temperature at a regular rate by diminishing the energy by 5 or 10 watt intervals.

The levulose sirup was evaporated in a vacuum to a concentration of 90 to 92 per cent solids, transferred to the crystallizer, and heated to about $55^{\circ} \mathrm{C}$. It was then seeded with levulose crystals and maintained in slow motion while crystallization proceeded. The growth of the crystals was observed frequently by examination under a microscope. The rate of crystal formation depended to an important degree upon the purity of the sirup. From sirups of high purity the crystallization proceeded so satisfactorily that the temperature could be dropped to about $25^{\circ} \mathrm{C}$. in 24 to 36 hours. Sirups of lower purity required four to five days. The process of crystallization is an art responding in high degree to the individual experience and skill of the operator, and the almost uniform success of the limited number of experiments described here suggests that an operator may accumulate sufficient skill to exercise a very complete control over a levulose massecuite.

At the completion of the crystallization the massecuite was centrifuged in the usual manner. The mother liquor ran off with some-

${ }_{33}$ B. S. Tech. Paper No. 259, 18, p. 303; 1924. 
what more difficulty than from a similar sucrose massecuite, as was to be expected, but this merely involved a slightly increased time. Before washing, the mother liquor was collected for weighing and analysis as nearly quantitatively as possible, the centrifuge casing being finally washed and dried. The crystals were then washed in the early experiments with water; in the later, with a levulose sirup. The high solubility caused a great loss of sugar when water was used, while the loss could be greatly diminished by using a sirup of high

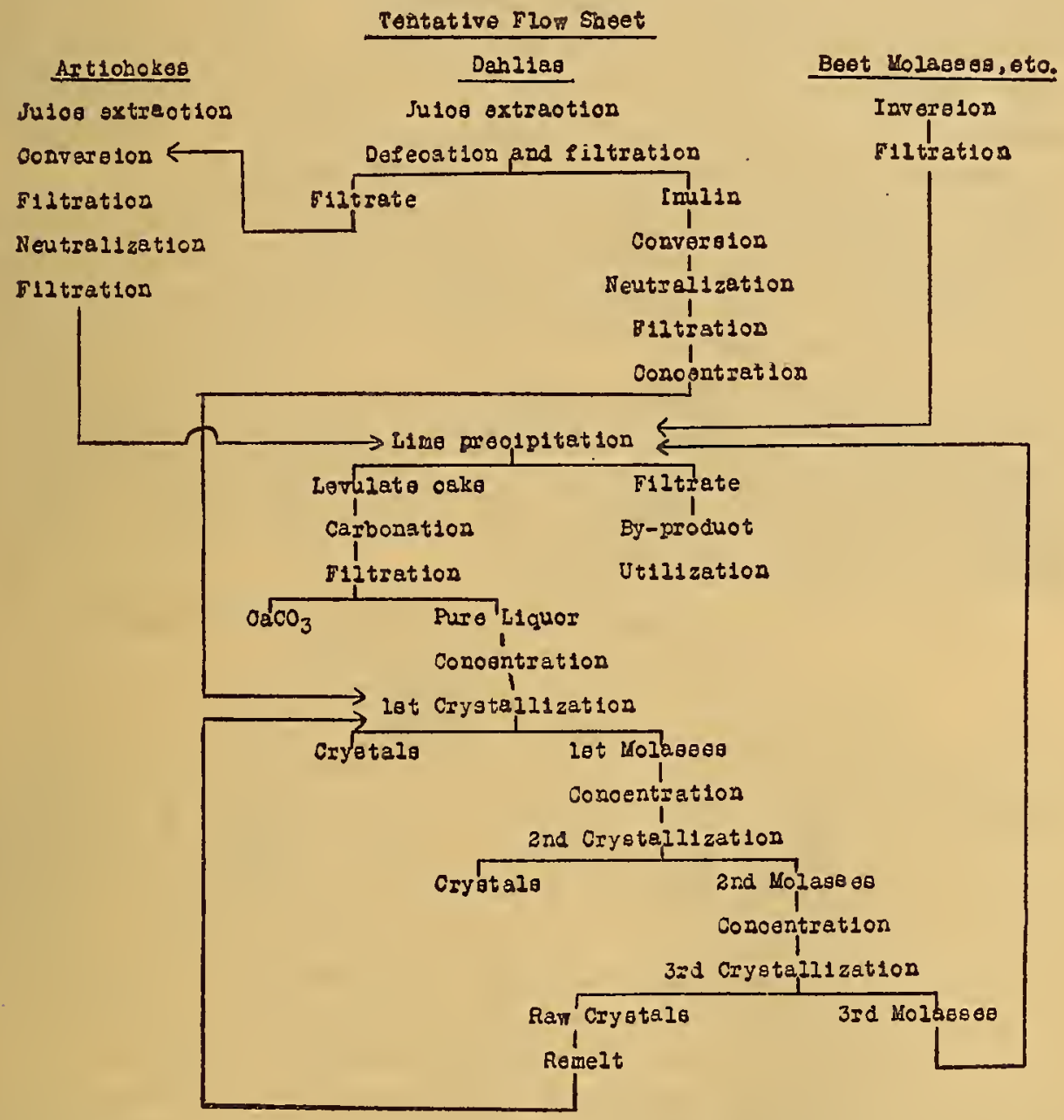

concentration. It is probable that in practice evaporator sirups of high purity would serve this prupose. It may prove desirable to subject the crystals to a final washing with a small quantity of 100 purity sirup. The washings were collected quantitatively and analyzed.

The mother liquors, in general, possessed a purity of about 82 per cent. While from these the crystallization proved to be considerably more difficult, the massecuites uniformly yielded a fairly white sugar, indicating that with accumulated experience an entirely satisfactory product may be obtained. 
The second molasses possessed purities of about 69 per cent. We have not as yet succeeded in obtaining acceptable massecuites from sirups of so low a purity by use of the crystallizers, but if such a sirup is concentrated to 92 or 93 Brix and is allowed to stand for several weeks it has been observed to deposit crystals slowly but abundantly. The technique of this low-purity crystallization will require much further study. We can, however, say with confidence that the crystallization is not inhibited by the accumulation of impurities, and that it will ultimately prove possible to obtain a raw levulose from these residual liquors. The final molasses may then be returned to the original precipitation process for the recovery of the remaining levulose. We have thus far discovered no tendency for any deleterious substances to accumuate in the reworked molasses.

The crystallization data thus far obtained are assembled in Table 13. Experiments 4, 5, and 6 were conducted on the sirups obtained from artichokes. The remaining sirups were obtained from miscellaneous sources, such as invert sugar, beet molasses, and dahlia juices. Experiment 9 was an attempt to produce a massecuite from a low-purity sirup. The crystallization, however, proceeded too rapidly and produced a large quantity of false grain which made the centrifuging extremely difficult. By a protracted period of centrifuging a raw levulose was obtained.

TABLE 13.-Data on the crystallization of levulose from aqueous solution (a) CRYSTALS WASHED WITH WATER

\begin{tabular}{|c|c|c|c|c|c|c|c|c|c|c|c|c|c|c|c|c|}
\hline \multirow[b]{2}{*}{ Experiment No. } & \multicolumn{4}{|c|}{ Massecuite } & \multicolumn{3}{|c|}{ Mother liquor } & \multicolumn{2}{|c|}{$\begin{array}{c}\text { Washing } \\
\text { sirup }\end{array}$} & \multicolumn{3}{|c|}{ Wash } & \multicolumn{4}{|c|}{ Crystals } \\
\hline & ตี่ & 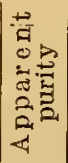 & $\begin{array}{l}\overrightarrow{\vec{n}} \\
\overrightarrow{00} \\
\overrightarrow{0}\end{array}$ & 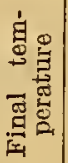 & $\stackrel{\leftrightarrow}{\mathscr{H}}$ & 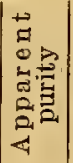 & 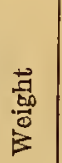 & 䓛 & $\begin{array}{l}\frac{\vec{c}}{E 0} \\
\stackrel{0}{0}\end{array}$ & $\stackrel{4}{M}$ & 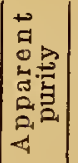 & 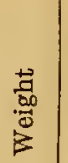 & 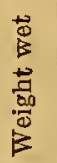 & 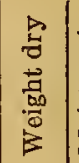 & 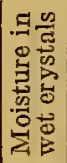 & 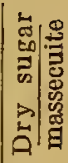 \\
\hline & 90.5 & $\begin{array}{r}P . c t \text {. } \\
93.8\end{array}$ & $\begin{array}{l}G . \\
1,291\end{array}$ & $\begin{array}{cc}{ }^{\circ} & C . \\
& \\
& \\
& \end{array}$ & 83.7 & $\begin{array}{c}P . c t \\
86.1\end{array}$ & $\begin{array}{l}G . \\
639\end{array}$ & & G. & 82.9 & $\left|\begin{array}{c}P . c t . \\
91.1\end{array}\right|$ & $\begin{array}{c}G . \\
164\end{array}$ & $G_{481}$ & $\begin{array}{c}G . \\
474.7\end{array}$ & $\begin{array}{l}\text { P.ct. } \\
1.31\end{array}$ & $\begin{array}{l}P . c t . \\
36.7\end{array}$ \\
\hline
\end{tabular}

(b) CRYSTALS WASHED WITH SIRUP OF ABOUT 50 BRIX

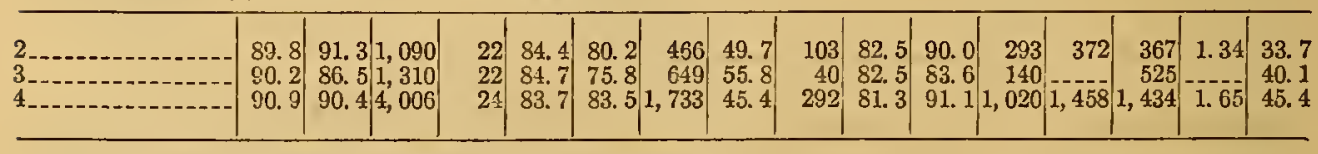

(c) CRYSTALS WASHED WITH SIRUP OF ABOUT 65 BRIX

\begin{tabular}{|c|c|c|c|c|c|c|c|c|c|c|c|c|c|c|c|}
\hline 5 & $\begin{array}{l}91.4 \\
90.6\end{array}$ & $\begin{array}{lll}93.3 & 1,380 \\
94.4 & 1,430\end{array}$ & $\begin{array}{l}26 \\
26\end{array}$ & $\begin{array}{l}84.6 \\
84.0\end{array}$ & $\begin{array}{l}83.6 \\
82.0\end{array}$ & $\begin{array}{l}546 \\
563\end{array}$ & $\begin{array}{l}63.7 \\
66.5\end{array}$ & $\begin{array}{r}95 \\
122\end{array}$ & $\begin{array}{l}81.9 \\
81.4\end{array}$ & $\begin{array}{l}89.8 \\
90.5\end{array}$ & $\begin{array}{l}200 \\
208\end{array}$ & $\begin{array}{l}696 \\
751\end{array}$ & $\begin{array}{l}685 \\
735\end{array}$ & $\begin{array}{l}1.58 \\
2.13\end{array}$ & $\begin{array}{l}49.6 \\
51.4\end{array}$ \\
\hline
\end{tabular}

(d) CRYSTALLIZATION FROM SIRUPS OF ABOUT 81 PURITY

\begin{tabular}{l|l|l|l|l|l|l|l|l|l|l|l|l|l|l|l|l|}
\hline $7 \ldots \ldots$ & 90.6 & 81.0 & 1,338 & 27 & 86.3 & 68.6 & 608 & 51.2 & 120 & 82.9 & 83.9 & 345 & 440 & 436 & 0.91 & 32.6 \\
\hline $8 .-1.5$ & 90.6 & 81.1 & 1,400 & 24 & 85.9 & 68.4 & 661 & 49.2 & 119 & 82.2 & 81.6 & 356 & 447 & 439 & 1.79 & 31.4 \\
\hline
\end{tabular}

(e) CRYSTALLIZATION FROM SIRUP OF 75.9 PURITY

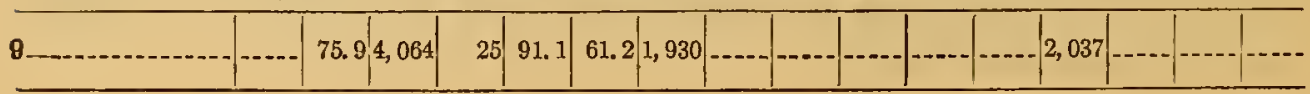




\section{BY-PRODUCTS}

Modern industry requires as complete a utilization of by-products as possible. At the present stage of this investigation it is obviously only possible to indicate the nature of these materials. The exhausted pulp of the Jerusalem artichoke will require disposition. It may be expected that this pulp will be palatable to cattle and can be utilized in much the same manner as the exhausted pulp of the sugar beet. The dahlia is entirely rejected by animals and will require other methods of disposal. Its powerful fiber suggests its adaptability to paper or fiber-board manufacture. It may, on the other hand, have a fuel value if sufficiently desiccated.

The filtrates from the lime precipitation process occupy a very considerable volume. They have a reducing sugar content of about 4 to 5 per cent. While so high a dilution militates against economic recovery, a fermentation process could conceivably be adapted to this product. The vinasse then could be utilized in the same manner as other vinasses. ${ }^{34}$

The only reagent which is required in large quantity is lime. Unless the lime should be found to accumulate silica and other deleterious impurities from the juices, it would appear feasible to reburn the carbonate which is recovered from the carbonation of the lime levulate or of the waste water, and thus reduce to a considerable degree the cost of this material.

\section{PROPERTIES OF CRYSTALLINE LEVULOSE}

Levulose crystallizes in the rhombic system. Previous investigators have reported that it separates from alcoholic solution in the form of needles which may attain a length of $10 \mathrm{~mm}$. By the methods of crystallization which have been described no tendency to form needles has been apparent. In every instance the crystals have taken the form of slightly tilted cubes which resemble en masse the ordinary cane sugar of commerce.

The sugar is somewhat hygroscopic in an atmosphere of high humidity. For this reason it will require protection against such humidities. It is probable that an ordinary paraffined carton will suffice for this purpose. For extended periods of time, particularly in winter months, the sugar exposed in an open vessel remains dry and sandy, but a rise in humidity affects it adversely. Even under the most adverse conditions, however, it retains quite indefinitely its whiteness and purity.

WASHington, July 7, 1925.

34 B. S. Circular No. 145. 



\section{,}




